\title{
Abiotic Stress: A Constraint in Farming
}

\author{
Gummadi Shirisha*, Harmeet Singh Janeja and Alla Rahul Reddy
}

Lovely Professional University, Punjab-144411, India

*Corresponding author

Keywords

Abiotic stress, drought, heat stress, salinity, water logging, mineral toxicity

Article Info

Accepted:

12 April 2021

Available Online:

10 May 2021

\section{A B S T R A C T}

Exponential growth of the population and industrialization resulted in adverse effect and tremendous change in the climatic patterns and lead to global warming and various other effects. This shift in weather patterns causes various stresses on plants. As plants play a major role in our lives including food, clothing and shelter, fighting these stresses for our survival is must. Abiotic stress factors like drought, high temperature, salinity, water logging and mineral toxicity causes disturbances and differences from germination to reproductive stages and such stress for longer periods are fatal to the plant. Drought, Heat and salinity are major among them as significant cultivated lands fall in arid, semi-arid and coastal regions of the country. Each of these has different effects on plants and their survival. So, extensive studies should be carried out to understand them and further work needs to be done to reduce the yield losses and improvise yields.

\section{Introduction}

Climate change shows several impacts on agriculture production. Any external condition that affects growth and yield of the plants is referred to as stress.. A stress in a plant normally represents sudden environmental changes. (Audil Gull, 2019). It causes a wide variety of plant reactions, such as altered gene expression, cell metabolism, growth rate changes, crop yields, etc. Studies revealed that Irreplaceable loss in the field of agriculture is caused due to abiotic stress. [(Boyer, 1982) (Bray, 2000)]. The plant needs a certain quantity of any abiotic environmental factor for optimum growth. Any deviation from such ideal external conditions, i.e. a chemical or physical environment excess or deficiency, is considered to be abiotic stress and severely affects the growth, development and/or productivity of plants. For instance, extreme temperatures, water logging, drought, insufficient mineral nutrients in the soil and excessive salinity of the soil are the abiotic 
stress factors effecting plants. Drought and salt stress, in particular, are increasingly severe threats to agriculture and the natural condition of the climate. (Hans-Werner Koyro, 2011)

Drought, heat and salinity have been effecting crop production (Bray, 2000) (Cushman, 2000) from the past two decades. A mixture of various abiotic stresses effect several crops [(Moffat, 2002) (Heyne, 1940) (Craufurd, 1993) (Jiang, 2001)]. For instance, many crops experience a combination of abiotic stress such as heat or salinity, in drought prone regions [(Moffat, 2002) (Heyne, 1940)].

Abiotic stress majorly impacts the internal functions of the plant. Environmental variation causes stress which disturbs the internal modification, physiology and biochemistry of the plants which further impacts negatively on the crop growth, development and yield (Summy yadav, 2020). Different abiotic stress which cause loss in agricultural production include drought, extreme/High temperatures, Low temperatures, water logging, salinity and mineral toxicity. Some of them are discussed below.

\section{Drought}

Drought condition is termed as a less availability or scarcity of minimum required water. This stress is caused due to the water deficiency retards the optimum growth and development in plants (Summy yadav, 2020). Amongst the abiotic factors, drought is considered the main factor resulting in reduced growth and development of plants and their produce. The plants exposed to drought stress typically vary depending on the stage of plant growth and other environmental factors (Shah fahad, 2017). Extreme droughts result in major reduction in crop yields due to adverse effects on plant growth, physiology and reproduction (Shah fahad, 2017). Drought during germination and seedling development affects the crop stand in the field. Flowering plants, when exposed to drought stress can lead to sterility. Drought caused at the preanthesis shortens the anthesis period while after anthesis, the grain filling percentage is affected (Shah fahad, 2017).

Frequent droughts results in accumulation of salts and ions in the upper layers of the soil around the root cause osmotic stress and ion toxicity (Amin Fathi, 2016). This reduces the germination rate (M. Farooq, 2008) and also disturbs water flow from xylem to adjacent elongating cells in higher plants, thereby restricting cell elongation (Shah fahad, 2017).

\section{Heat stress}

Since the seventies, industrialization caused up to $0.18^{\circ} \mathrm{C}$ increase every 10 years on average in the total global temperature (Ali Raza, 2019). Heat stress can affect at any stage of development from germination to reproduction significantly reducing the yield of the plant depending on the temperature, duration of stress and type of the plant(Ashwani Pareek, 2020). Sometimes, cells die within minutes on exposure to extreme temperatures. Temperature greater than that of the optimum range results in the reduction of photosynthetic activity which in turn delays the plant growth eventually leading to death of the plant. Heat also alters the rate of respiration in plants. Study suggests plants exhibit morphological characteristics if the plant's respiration rate increased from 15 to 40 (Deepak K. Ray, 2019).

The differential effect of heat stress effects stability of different proteins, membranes, RNA species and the biological structures, altering the efficiency of enzyme reactions in the cell where major physiological processes interfere and create metabolic imbalances which reduces germination percentage, plant 
emergence, abnormal seedlings, poor seedling vigour, reduced radical growth and plume growth of geminate seedlings.

It also leads to a loss of the cell water content, which eventually reduces cell size and growth. Scorching and bruising of leaves and twigs, branches and stalks, leaf cell death, abscission, inhibition of root and shoot growth, fruit discolouration are the morphological indicators of stress.

Heat greatly affects the state of the plants, leaves and stomatal concentration.

The most sensitive are the reproductive tissues and their disturbance due to increase in temperature leads to reduction the grain yield. Heat stress degrades meiosis, decreased pollen germination and growth of the pollen tube, reduced viability, stigmatic and style anomalies, reduced stigmatic pollen grains, disrupted fertilisation process, endosperm growth barriers and unfertilised embryos. (Mirza Hasanuzzaman, 2013).It also reduces pollen viability and shortens grain filling. Study suggests a $3-4^{\circ} \mathrm{C}$ increase in temperature causes yield reduction by $15-35 \%$ (Foyer, 2018).

\section{Salinity}

Salinity is a significant yield controlling factor that poses a serious challenge to agriculture around the world (Ashwani Pareek, 2020). Drought-induced water shortages also go hand-in-hand with salinity. The toxicity of ion as well as the depletion of water table potentials leads to serious plant growth reductions (Calleja-Cabrera, 2020). Salinity causes osmotic stress and ion toxicity, two main effects on crop plants. Osmotic pressure due to salinity increases the osmotic stress in the plant cells, thereby limiting the plant ability to take water and minerals like $\mathrm{K}^{+}$and $\mathrm{Ca}^{2+}$. This causes some effects like lower cell expansion, membrane function, assimilation and cytosolic metabolism reduction (Audil Gull, 2019).

Physiological responses like loss of turgor, reduced leaf water potential, decrease in stomatal conductance, reduced internal $\mathrm{Co}_{2}$ concentration, reduced photosynthesis rate, reduced growth and leaf senescence and biochemical responses like osmolytes accumulation such as proline, glycine, betaine and TSS are the adverse effects of salinity. Crops like barley, sugar beet and cotton are highly tolerant to salt whereas crops like sweet potato, maize and wheat are highly sensitive to salinity and results in reduced yield(J. CallejaCabrera, 2020).

\section{Water logging}

Water logging is the stagnation of water and over accumulation of water in the water table. The soil generally absorbs surface water and restores the natural condition of its surface but when it fails to do so, it leads to a situation known as water logging, where the ground is soaked up and the water is raised above the surface level. In India, 2.04 million hectares of land is affected due to water logging out of which 1.4million hectare is affected by stagnated water and 0.64 million hectares is affected due to increase in water table. Water logging results in reduced natural air intake into the soil, decreased oxygen concentration and elevated carbon dioxide and ethylene levels (Rinkesh, 2020). The restriction of air causes anaerobic condition affecting the crop growth and development (Iduna Arduini, 2019). 
Table.1 Effects of drought on growth stages and its yield reduction in different crops

\begin{tabular}{|c|c|c|}
\hline Crops & $\begin{array}{c}\text { Effects on growth stage and its } \\
\text { yield reduction }\end{array}$ & References \\
\hline Rice & $\begin{array}{l}\text { Effects during mild stress of } \\
\text { reproductive stage }(53-92 \%) \text { whereas } \\
\text { severe stress }(48-94 \%) \text {. } \\
\text { Also occurs during mild stress of } \\
\text { grain filling }(30-55 \%) \text { whereas } \\
\text { severe stress }(60 \%) \text {. }\end{array}$ & $\begin{array}{l}\text { (Honor Renee Lafitte, 2007) } \\
\text { (Jayampathi Basnayake, 2006) }\end{array}$ \\
\hline Maize & $\begin{array}{l}\text { Effects during vegetative phase }(25- \\
60 \%) \text {, reproductive stage }(63-87 \%) \\
\text { and grain filling stage }(79-81 \%) \text {. }\end{array}$ & $\begin{array}{l}\text { (Atteya, 2003) } \\
\text { (A. Y. Kamara, 2004) } \\
\text { (P. Monneveux, 2006) }\end{array}$ \\
\hline Chickpea & $\begin{array}{l}\text { Effects during reproductive stage } \\
(45-69 \%)\end{array}$ & (Harsh Nayyar, 2006) \\
\hline Barley & $\begin{array}{l}\text { Effects during seed filling stage (49- } \\
57 \%)\end{array}$ & (Samarah, 2005) \\
\hline Pigeon pea & $\begin{array}{l}\text { Effects during reproductive stage } \\
(40-55 \%)\end{array}$ & (Nam, 2001) \\
\hline Sunflower & $\begin{array}{l}\text { Effects during reproductive stage } \\
(60 \%)\end{array}$ & $\begin{array}{l}\text { (Mazahery- Laghab, Nouri, \& } \\
\text { Zare Abianeh, 2003) }\end{array}$ \\
\hline Potato & Effects during flowering stage (13\%) & (Kawakami J., 2006) \\
\hline
\end{tabular}

Table.2 Effects of mineral toxic symptoms in plants

\begin{tabular}{|c|l|}
\hline Mineral nutrients & \multicolumn{1}{|c|}{ Mineral toxic symptoms } \\
\hline Nitrogen-N & $\begin{array}{l}\text { Dark green leaves and foliage. } \\
\text { Yellowing of effected leaves. } \\
\text { Leaf tips turns down. }\end{array}$ \\
\hline Phosphorus-P & $\begin{array}{l}\text { Limitation of pH } \\
\text { Availability of copper and zinc due excess P. }\end{array}$ \\
\hline Potassium-K & Necrosis occurs in the leaf tip and margins. \\
\hline Calcium- Ca & $\begin{array}{l}\text { Magnesium and Potassium deficiencies occur due to } \\
\text { increase in calcium level. }\end{array}$ \\
\hline Magnesium- Mg & $\begin{array}{l}\text { Magnesium toxicity are very rare, does not exhibit visible } \\
\text { symptoms. }\end{array}$ \\
\hline Sulfur- S & $\begin{array}{l}\text { Reduce lead size. } \\
\text { Stunted growth of the plant. } \\
\text { Scorching or yellowing of leaves occurs at edges. }\end{array}$ \\
\hline Boron- B & $\begin{array}{l}\text { Leaf necrosis. } \\
\text { Leaf falling. } \\
\text { Leaf necrosis. } \\
\text { Uneven death of the plants. }\end{array}$ \\
\hline Chlorine- Cl & $\begin{array}{l}\text { Premature yellowing of leaves. } \\
\text { Necrosis in older leaves. }\end{array}$ \\
\hline
\end{tabular}




\begin{tabular}{|c|l|}
\hline Copper- Cu & $\begin{array}{l}\text { Reduce the root growth. } \\
\text { Compete with nutrient uptake like Fe, Mo, and } \mathrm{Zn} . \\
\text { Branching is reduced. } \\
\text { Plant death occurs. }\end{array}$ \\
\hline Iron- Fe & $\begin{array}{l}\text { Occurs due to excessive application of iron. } \\
\text { Occurs due to low soil pH }\end{array}$ \\
\hline Manganese- Mn & $\begin{array}{l}\text { Occurs due to excessive application of fertilizers. } \\
\text { Occurs due to pH less than 5.5 } \\
\text { Patches are formed on the older leaves. }\end{array}$ \\
\hline Molybdenum- Mo & Toxicity is not common. \\
\hline Zinc- Zn & $\begin{array}{l}\text { Occurs due to low pH } \\
\text { Causes growth reduction and leaf chlorosis. }\end{array}$ \\
\hline
\end{tabular}

Fig.1 Different factors affecting abiotic stress

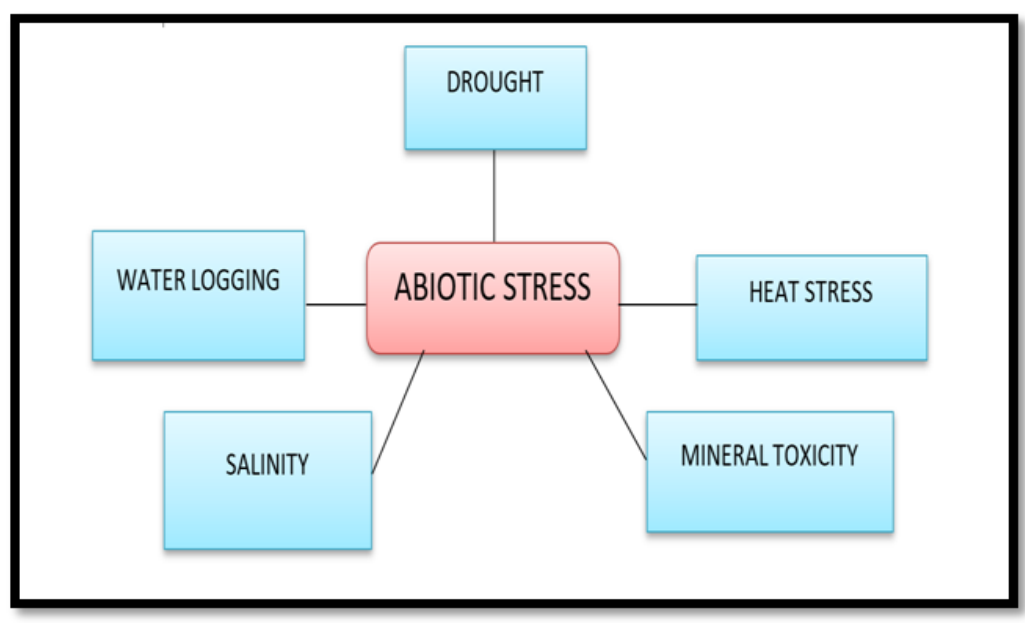

Fig.2 Different effects of drought stress on plant growth and development.

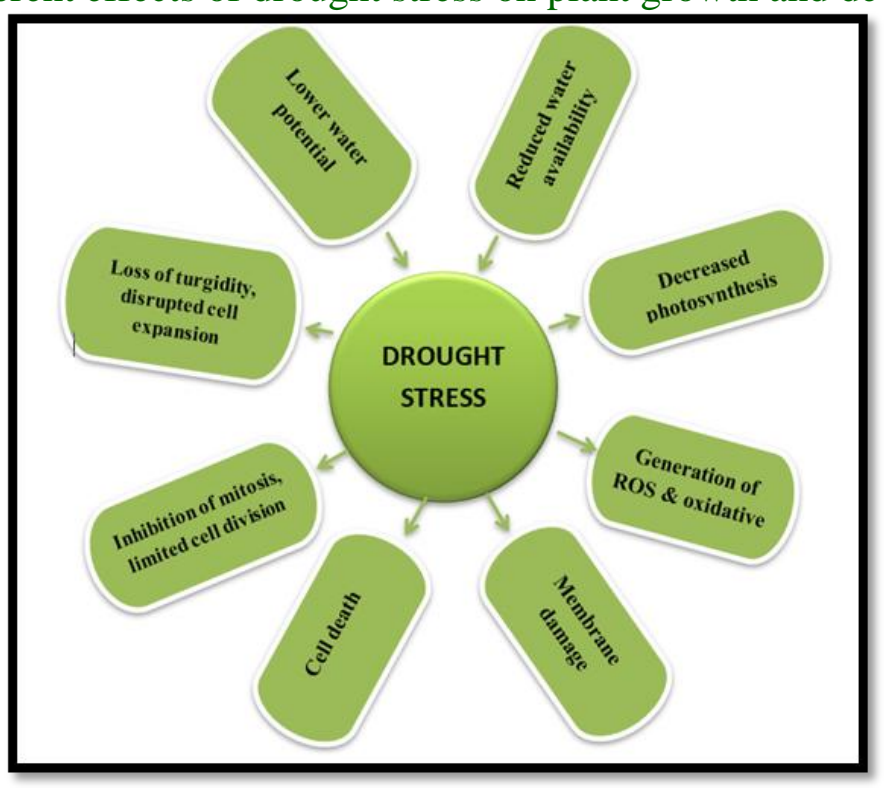


Fig.3 Different effects of heat stress on plant growth and their development.

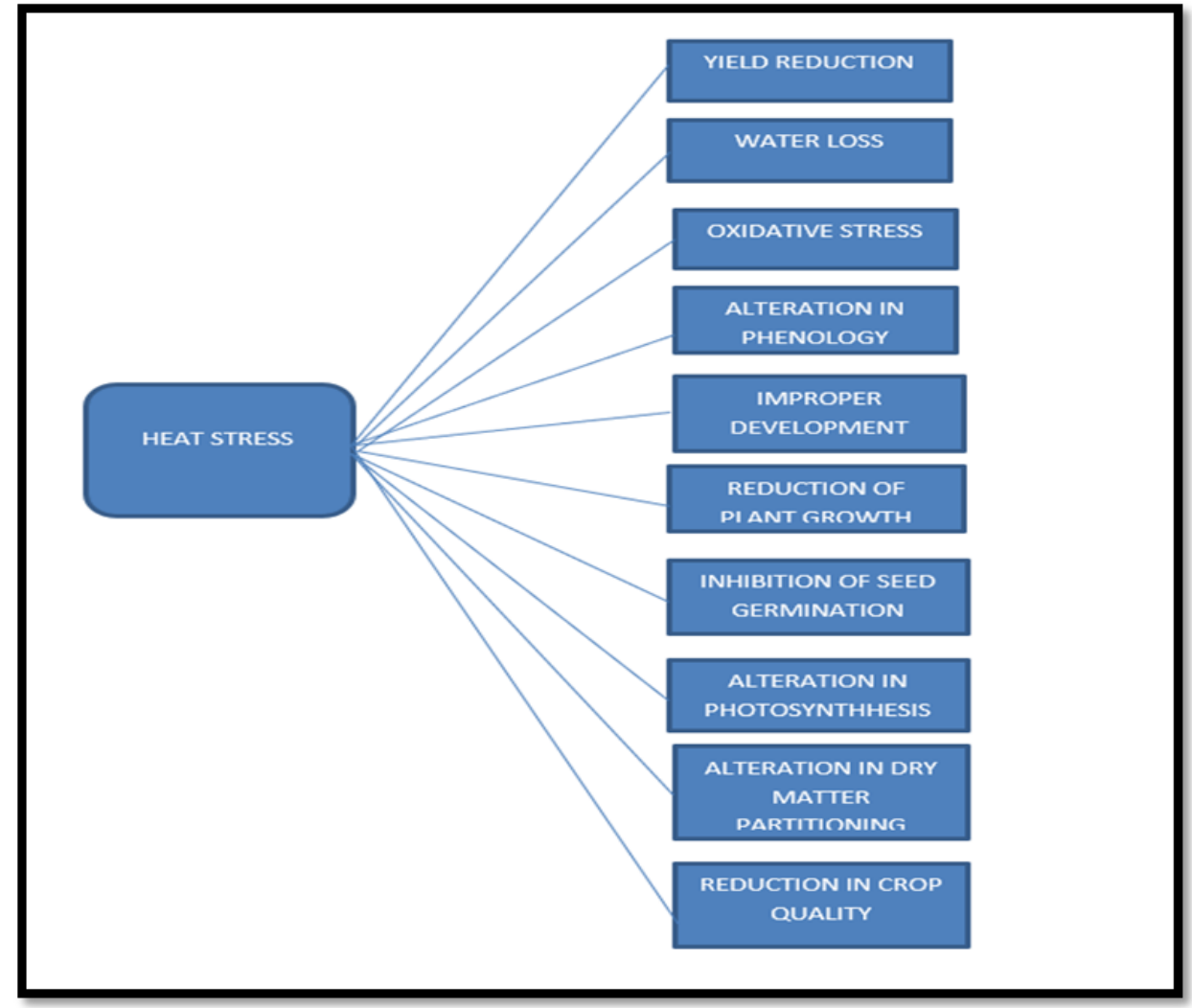

Fig.4 Different effects of salinity stress on plant growth and development.

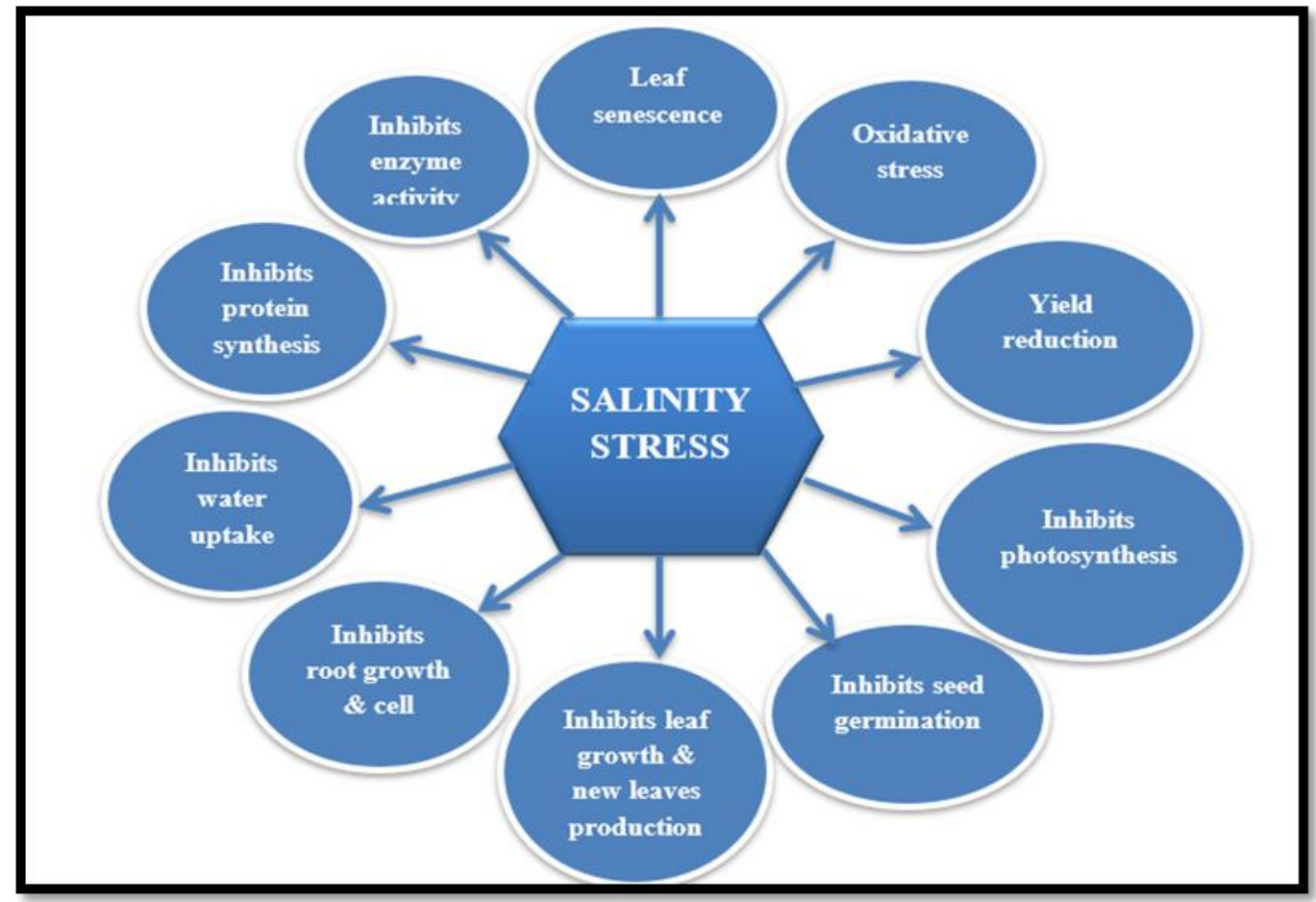


Fig.5 Different effects of water logging on plant growth and development.

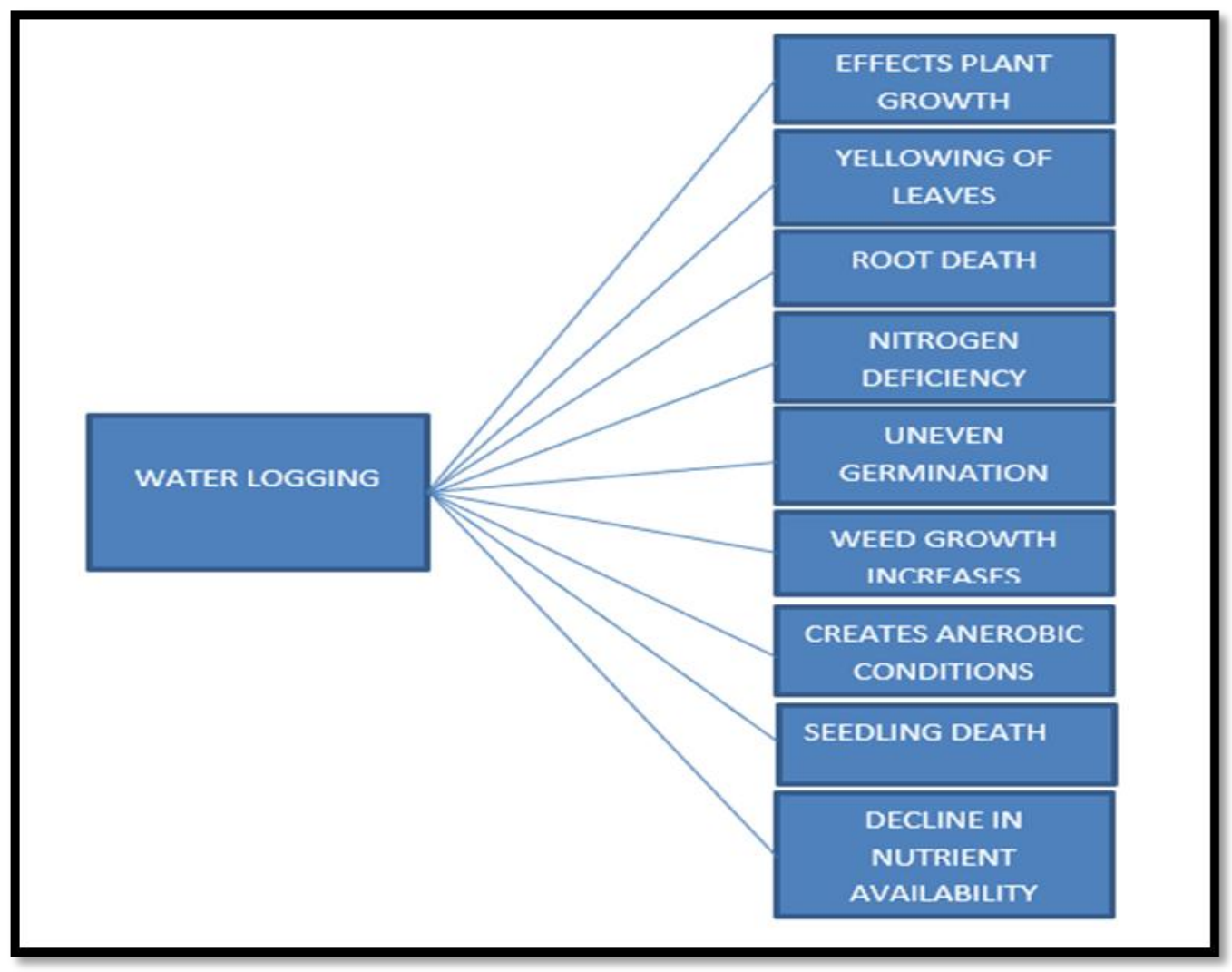

Water logging effects germination of seeds and the initial growth stages. If plants grow rapidly, the root tips begin to deteriorate within a few days. It also causes loss of nitrogen through leaching and de-nitrification (Ploschuk RA, 2018).

Logging causes various effects like harmful salt accumulation, soil temperature drop, decrease in maturity duration, anaerobic state formation in the root area and it is difficult to carry out tillage operations. It also results in occurrence of anoxia which causes root disease(Robyn Anderson, 2019).

A flood physiological disorder includes impaired water intake, nutrient absorption, hormonal equilibrium and photosynthesis, which result in poor plant growth.
It also leads to rhizosphere reduction, leading to a decrease of the mineral ions and useful elements(Baizhao Ren, 2016).

In maize, reduction of chlorophyll, leaf area index and mitochondrial respiration is affected. The structure of membrane changes due to the destruction of cell, vacuoles, nucleus edge and membrane of chloroplast which leads to reduction in grain yield(Baizhao Ren, 2016). In cotton, the yield is decreased based on the impact of water logging on the crop i.e., flowering is reduced to $38.8 \%$, the squaring to $27.9 \%$, the planting to $18.3 \%$ and the opening of bollard to 7.6\%(Xiaosen Wang, 2017).

The flood conditions in legumes will damage nitrogen assimilation by weakening the ability to fix symbiotic nitrogen. 
Water logging causes yield reduction in the range of 15 to $25 \%$ in wheat and barley, 30 to $45 \%$ in rapeseed and 50 to $90 \%$ in field peas, depending on the duration, soils and genotype of the crops (Ploschuk, 2018).

\section{Mineral toxicity}

Excessive amounts of mineral nutrients in the soil are termedas mineral toxicity. It limits the agriculture in many areas of the world(Brown, 2010). Plants use water, oxygen and carbon dioxide for its growth and development. Along with these, plants require other 14 mineral elements(Brown, 2010). These elements consist of both micro and macro nutrients. Availability of less nutrients to plant results in deficiency where as more nutrients results in toxicity(P. C. Nagajyoti, 2010). Macro elements are nitrogen $(\mathrm{N})$, phosphorus $(\mathrm{P})$, potassium $(\mathrm{K})$, calcium $(\mathrm{Ca})$, magnesium $(\mathrm{Mg})$ and sulfur (S). They required large quantity for plant. Micro elements are chlorine $(\mathrm{Cl})$, boron $(\mathrm{B})$, iron $(\mathrm{Fe})$, manganese $(\mathrm{Mn})$, copper $(\mathrm{Cu})$, zinc $(\mathrm{Zn})$, nickel $(\mathrm{Ni})$ and molybdenum (Mo). They required small quantity for plant (Brown, 2010).

Toxicity shows its effects in different plant growth stages and causes stunted growth, delayed fruit set and maturity, if this toxicity is increased, it further shows purple tints on the leaves, veins and stems whereas young leaves show curling up of leaves, breaking of petioles, roots and root tips turns brown color further, resulting in death of the whole plant. On the other side increase of both micro and macro nutrients more than its necessity causes toxicity in the plants. Deficiency symptoms of $\mathrm{N}, \mathrm{P}, \mathrm{K}$, and $\mathrm{Mg}$ occur on old leaves, while the others symptoms appear first on young leaves later on older leaves for $\mathrm{Ca}$ and other nutrients. Born $(\mathrm{B})$, sodium $(\mathrm{Na})$, carbonate $\left(\mathrm{CO}_{3}\right)$, bicarbonate $\left(\mathrm{HCO}_{3}\right)$, aluminum $(\mathrm{Al})$ and manganese $(\mathrm{Mn})$ leads to toxicity at different growth stages of the plants (Constable, 2010).

The global temperature will increase by $3-5^{\circ} \mathrm{C}$ in the upcoming years due to increase in human activities like industrialization, irrational use of pesticides and other field operations causes chemical toxicity. In near future, it is predicted that abiotic stress in plants is going to increase tremendously due to the climatic adversities. Hence, there is an immediate need to understand the basis of stress and to develop tolerant and resistant varieties abiotic stress which should meet the nation's food demand. There have been multiple advancements in the field of plant breeding including transfer of genes and development of new varieties tolerant and resistant to stress. Such methods should be employed further coupled with advanced techniques to help fight the stress situation and improvise crop yields.

\section{References}

Ali Raza, A. R. (2019). Impact of climate change on crops adaptation and stratagies to tackle its outcome: A Review. MDPI, 1-29.

Amin Fathi, D. B. (2016). Effect of Drought Stress and its Mechanism in Plants. International Journal of Life Sciences, 1-6.

Ashwani Pareek, O. P. (2020). Mitigating the impact of climate change on plant productivity. Journal of Experimental Botany, 451-456.

Atteya, A. (2003). Alteration of water relations and yield of corn genotypes in response to drought stress. 1-14.

Audil Gull, A. A. (2019). Biotic and Abiotic Stresses in plants. IntechOpen, 1-6.

Baizhao Ren, J. Z. (2016). Effects of Waterlogging on Leaf Mesophyll Cell Ultrastructure and Photosynthetic Characteristics of Summer Maize. PLOS ONE, 1-22. 
Boyer, J. (1982). Plant productivity and environment. Science, 443-448.

Bray, E. E. (2000). Responses to abiotic stresses. Biochemistry and molecular biology of plants, 1158-1249.

Brown, P. J. (2010). Plant nutrition for sustainable development and global health. Annals of botany, 1073-1080.

Calleja-Cabrera, J., M. B.-S. (2020). Root Growth Adaptation to Climate Change in Crops. Frontiers in plant science, 123.

Constable, S. C. (2010). Plant Responses To Mineral Deficiencies and Toxicities. Springer, 142-161.

Craufurd, P. a. (1993). Effect of heat and drought stress on sorghum. Exp. Agric., 77-86.

Cushman, J. A. (2000). Genomic approaches to plant stress tolerance. current opinions in plant biology, 117-124.

Deepak K. Ray, P. C. (2019). Climate change has likely already affected global food production. PLOS ONE, 1-18.

Farooq, M., A. W. (2008). Plant drought stress: effects, mechanisms and management. EDP sciences, 153-188.

Foyer, O. P. (2018). Climate resilient crops for improving global food security and safety. wiley, 877-884.

Hans-Werner Koyro, P. A. (2011). Abiotic Stress Responses in Plants: An Overview. Sprinnger Science+Business Media, 1-28.

Harsh Nayyar, S. K. (2006). Differential sensitivity of Desi (small-seeded) and Kabuli (large-seeded) chickpea genotypes to water stress during seed filling: Effects on accumulation of seed reserves and yield. Journal of the Science of Food and Agriculture, 2076-2082.

Heyne, E. a. (1940). Genetic studies of heat and drought tolerance in maize. e. J. Am. Soc. Agro, 803-814.
Honor Renee Lafitte, G. Y. (2007). Whole plant responses, key processes, and adaptation to drought stress: The case of rice. Journal of experimental botany, 169-175.

Iduna Arduini, M. K. (2019). Crop respose to climate change. Frontiers in plant science, 4-5.

Jayampathi Basnayake, S. F. (2006). Contribution of potential yield, drought tolerance and escape to adaptation of 15 rice varieties in rainfed lowlands in Cambodia. The reginal institute online publication, 15.

Jiang, Y. A. (2001). Drought and heat stress injury to two cool season turfgrasses in relation to antioxidant metabolism and lipid peroxidation. Crop Science, 436442.

Kamara, A. Y., A. M.-A. (2004). The influence of drought stress on growth, yield and yield components of selected maize genotypes. The Journal of Agricultural Science, 43-50.

Kawakami J., I. K. (2006). Soil water stress and the growth and yield of potato plants grown from microtubers and conventional seed tubers. ELSEVIER, 89-96.

Mazahery- Laghab, H., Nouri, F., \& Zare Abianeh, H. (2003). Effects of the reduction of drought stress using supplementary Irrigation for Sunflower (Helianthus annuus) in dry farming conditions. AGRIS, 81-86.

Mirza Hasanuzzaman, K. N. (2013). Physiological, Biochemical, and Molecular Mechanisms of Heat Stress Tolerance in Plants. International Journal of Molecular Sciences, 96439684.

Moffat, A. (2002). Finding new ways to protect drought-stricken plants. Sciene, 1226-1229. 
Monneveux, P., C. S. (2006). Drought Tolerance Improvement in Tropical Maize Source Populations: Evidence of Progress. Crop sciences, 180-191.

Nagajyoti, P. C., K. D. (2010). Heavy metals, occurrence and toxicity for plants: a review. Springer, 199-216.

Nam, N. H. (2001). Effect of timing of drought stress on growth and grain yield of extra-short-duration pigeonpea lines. The Journal of Agricultural Science, 179-189.

Ploschuk RA, M. D. (2018). Waterlogging of winter crops at early and late stages: impacts on leaf physiology, growth and yield. frontier inplant sciences, 133.

Rinkesh. (2020). Types, causes, effects and solution to waterlogging-conserve energy. Retrieved from Conserve energy future: https://www.conserveenergy-future.com/types-causeseffects-solutions-waterlogging.php

Robyn Anderson, P. E. (2019). Climate change and the need for agricultural adaptation. Elsevier, 197-202.

Samarah, N. H. (2005). Effects of drought stress on growth and yield of barley. INRA, EDP Sciences, 145-149.

Shah fahad, A. A. (2017). Crop production under drought and heat stress: plant responses and management options. frontiers, 1-16.

Summy yadav, P. m. (2020). Effects of abiotic stress on crops. Intechopen, 1-21.

Xiaosen Wang, Z. D. (2017). Effect of Waterlogging Duration at Different Growth Stages on the Growth, Yield and Quality of Cotton. PLOS ONE, 114.

\section{How to cite this article:}

Gummadi Shirisha, Harmeet Singh Janeja and Alla Rahul Reddy. 2021. Abiotic Stress: A Constraint in Farming. Int.J.Curr.Microbiol.App.Sci. 10(05): 348-357.

doi: https://doi.org/10.20546/ijcmas.2021.1005.042 